Hyperboreus", a kind of repository of contemporary inventions and experiments. In the same year Charles XII made him assessor in the College of Mines. His writings from that time onwards, published and unpublished, ranged over the whole field of science. In 1721 he wrote his "Prodromus Principiorum Rerum Naturalium", in 1722, a work on geology, in 1734 published in three volumes his "Opera Philosophica et Mineralia", in 1741 his "Economy of the Animal Kingdom" and in 1744-45 his "Animal Kingdom", with which his course as a natural philosopher ended. In London in 1749-56 he published his "Heavenly Arcana" and this was followed by some two score of theological works. $\mathrm{He}$ himself made no attempt to found a sect, but his followers established "the New Church signified by the New Jerusalem in the Revelation" and "Sweden. borgians' are to-day found all over the world.

THE removal of Swedenborg's body to Sweden in 1908 was but a part of a movement for the recognition of his genius as a man of science. In 1901 Dr. Max Neuberger, of Vienna, gave an address to an assembly of German naturalists and physicians entitled "Swedenborg's References to the Physiology of the Brain", in which he pointed out how Swedenborg had anticipated many modern discoveries. Dr. Neuberger next addressed a communication to the Academy of Sciences of Stockholm in which he expressed his regret that Swedenborg's manuscript on the brain had not been published. A committee was appointed to investigate the matter. On May 29, 1903, Prof. Gustaf Retzius, the president of the Academy, presented a report on the investigation to the Congress of Anatomists at Heidelberg. This led to a further examination of the manuscripts, and Dr. Retzius proposed that the Academy should issue an edition of Swedenborg's scientific and philosophical works. Even before this, proposals had been put forward for the founding of a museum for the preservation of portraits, relics and other Sweden. borgiana. Emerson wrote of Swedenborg: "He had great modesty and gentleness of bearing. His habits were simple; he lived on bread, milk and vegetables ; he lived in a house situated in a large garden. . . . $\mathrm{He}$ is described, when in IJondon, as a man of a quiet, clerical habit, not averse to tea and coffee, and kind to children. He wore a sword when in full velvet dress, and whenever he walked out carried a goldheaded cane. There is a common portrait of him in antique coat and wig, but the face has a wandering or vacant air."

\section{Scientific Delegation to India}

OUR correspondent, writing from Bombay on January 15, says: Some sixty members of the scientific delegation to India, including the president, Sir James Jeans, embarked on the S.S. Strathaird at Bombay on January 15 for the homeward voyage. Of these, nearly all had made the whole or part of the tour in Southern India arranged to take place after the Congress in Calcutta. This tour embraced visits to Madras, Mysore, and Bangalore, which none would willingly have missed. After a hot journey south, Madras received the delegation with a very perfect day, during which the University gave a luncheon, and most of the delegates attended a garden party arranged by the city in honour of the Viceroy. The small but very attractive aquarium, and other points of interest, were visited. The wonders of Mysore will never be forgotten by the visitors. They were received as guests of the State throughout their too short sojourn and were shown many of the institutions which are there maintained by an enlightened Government, while when darkness fell they viewed with amazement the illuminated fountains at the great power dam on the Cauvery, and the blaze of lights from the city as seen from Chamundi Hill. At Bangalore the Indian Institute of Science and other institutions were visited, and the party was entertained to tea by the Dewan Sahib of Mysore.

"AT all three cities visited during this southern tour, as indeed at every city visited throughout India, members of the delegation have freely responded to the many calls upon them for lectures, and all, whether so occupied or not have had constant opportunity for the renewal of contacts with old students now occupying responsible positions in the places visited, and for making new acquaintanceships with workers in their various fields of interest. The whole spirit of the visit has been one of mutual and practical help, and nothing has impressed us more than the immense interest of the community in the delegation, and especially that of the students who have thronged the lectures and incidentally demanded of us inconceivable numbers of autographs. The visit has been said, by many influential Indians, to have been a great event for India : certainly it has been so for the delegation."

\section{Museums and the Research Worker}

Some aspects of recent criticism of ethnographical collections in the museums of Great Britain are considered on p. 179 of this issue of Nature. It cannot be emphasized too frequently that the great national collections-the question under discussion cannot affect the smaller museums except in so far as they are prepared to specialize-being supported out of public funds, it is their bounden duty to perform a function of public utility; whether that may be, as is now generally required of them, that they should take their share in making efficient and supplementing the machinery of general education, or the more highly specialized function of assisting the research worker. To the latter rather than to an attachment to a traditional system must be attributed the classificatory organization which has been subjected to criticism. For it must not be forgotten that the great national collections, as well as the smaller ethnographical museums, some highly specialized, such as the Pitt-Rivers Museum at Oxford, the Museum of Archæology and Ethnology at Cambridge, or the Manchester University Museum, have been the laboratories for the scientific researches of the 
technologist in the broader sense, the student of material culture. It is upon this class of evidenee that the archæologist, the ethnologist and the student of early culture generally so largely rely. In the modern museum building, however, the trend of development is to make provision for the worker in technological research by withdrawing the bulk of the material in which he is interested from public exhibition, while the public galleries are given over to the more striking objects or to those of most educative value to the public. Doubtless when more space is given to our great public collections, the same method of procedure will be followed, and the public galleries will then be devoted to regional methods of display, in so far as these may have approved themselves as the most effective for purposes of instruction.

\section{Publication of Old Scientific Works}

A smaxl committee, presided over by Prof. B. Nemeč, met at Prague on December 3 and 4 to study, on behalf of the International Organisation for Intellectual Co-operation, the possibility of publishing old scientific works. This question had been raised by Prof. Nemeč, on behalf of the Czechoslovak Research Council, and had been adopted as part of the plan of scientific work of the International Organization for Intellectual Co-operation, by the executive committee of the International Council of Scientific Unions, acting as a committee of scientific advisers. The committee at Prague unanimously agreed that it would be desirable to publish a number of manuscripts or works on the exact and natural sciences, printed copies of which are extremely rare or almost inaccessible. A series of this kind would show the common origins of modern scientific culture and would be of great value to all savants interested in the historical development of the sciences. Considering the strictly international character of the undertaking, the committee felt that it should be entrusted to the International Organisation for Intellectual Co-operation. Further, the series should not be confined to one branch of science alone and it should embrace all the periods in the development of science since the Middle Ages.

THE publications envisaged may be divided into two series: Facsimiles relating to very rare manuscripts or works containing engravings or illustrations indispensable for the value of such works; and reprints of fundamental classical works in the development of the sciences, copies of which are extremely rare or no longer obtainable, including manuscripts that have never been printed. The committee suggested the publication in facsimile of the following manuscripts in the order given : (1) "De Revolutionibus orbium coelestium", by Nicolaus Copernicus ; (2) "De proprietatibus rerum", by Bartholomeus Anglicus (facsimile reproduction of the illustrations which appeared in all the editions, summary of each chapter of the original work, and a biography of the author); (3) "Micrographia", by Robert Hooke. In addition, the committee suggested the reprinting of the following very rare works and hitherto unpublished manuscripts in the order given : (1) "New System of Chemical Philosophy", by John Dalton; (2) a selection of letters from the scientific correspondence of Johannes Hevelius, astronomer and selenographer, the greater part of which is at the Bibliothèque Nationale, Paris ; (3) "Opuscula Botanitii argumenti", by Rudolf Camerarius ; (4) "De solido intra solidum naturaliter contento", hy Nicolaus Steno ; (5) "Origin of Species", by Darwin (a reprint of the first edition, 1859); (6) "Expériences pour servir à l'histoire de la génération des animaux et des plantes", by Lazaro Spallanzani; and (7) "Disquititio de sexu plantarum", by Linnæus.

\section{Excavations in North Syria}

At the Friday evening discourse at the Royal Institution on January 21, Sir Leonard Woolley described "Excavations in North Syria". The object of the North Syrian Expedition has been to trace such relations as may have existed between Asia and the early Greek world, especially during and before the rise of the Cretan civilization. Two sites were chosen on the trade-route afforded by the Orontes valley. One was at al Mina, at the river mouth, one at Atchana in the Amk plain where the road debouches from the mountain range and runs across open country past Aleppo to Carchemish and the Mesopotamian centres. At al Mina, underlying the ruins of the crusading port of St. Simeon, there were found nine further strata giving a continuous record of commercial activity from 300 B.c. back to the beginning of the eighth century. During the fifth and fourth centuries Athens, in spite of the longdrawn crisis of the Persian wars, enjoyed a trade monopoly with Persia. In the sixth century B.c. the bulk of the trade was in the hands of the Rhodian manufacturers, but Corinth, Naukratis and Lesbos secured a certain amount of it and Cyprus was still selling goods in Asia although in greatly reduced measure. In the seventh century, judging by al Mina, Cyprus entirely controlled the market; of all the imported pottery found there scarcely a sherd is not Cypriote. This domination had come about quite suddenly. It was a natural result of the wealth of the Asiatic clientele that the al Mina merchants imported always the best wares that were to be obtained; from each manufacturing centre the finest quality was selected and the centre changed according as its level of production rose or fell.

THE earlier strata of al Mina have been eroded by the river; for the period preceding the eighth century we have to look at the second site. The topmost stratum at Atchana is dated by imported Mycenæan pottery to the twelfth century B.c. In the second stratum below this, dated to the 15th-14th centuries, there are the earlier Mycenæan wares side by side with a remarkable painted pottery which is undoubtedly local, in some aspects identical with the 'Hurrian' wares found on other sites, in others altogether novel in Asia but strikingly reminiscent of Knossos. The city in which this pottery occurs, and 